\title{
FOXO3 Gene
}

National Cancer Institute

\section{Source}

National Cancer Institute. FOXO3 Gene. NCI Thesaurus. Code C28519.

This gene is involved in transcriptional regulation and apoptosis. 